\title{
THE JANIRID ISOPODS (CRUSTACEA, ISOPODA, ASELLOTA) LIVING ON THE SEA STAR ECHINASTER BRASILIENSIS MÜLLER \& TROSCHEL AT SÃO SEBASTIÃO CHANNEL, SOUTHEASTERN BRAZILIAN COAST, WITH DESCRIPTION OF A NEW SPECIES
}

\author{
Ana Maria Setubal Pires ${ }^{1}$
}

\begin{abstract}
Three species of janirid isopods were found on the sea star Echinaster brasiliensis Müller \& Troschel collected in São Sebastião Channel, southeastern Brazil. Janaira gracilis Moreira \& Pires and Carpias nereus (Pires) were previously known from the area and Carpias asterophilus, sp.n. is described. The three isopod species were found together on the dorsal surface of the sea star, and juveniles performed nearly $73 \%$ of the population. The janirids presented homeochromy with the sea stars, and food and shelter were the observed benefits that the crustaceans received from the association. A key to separate the species of Carpias with a spoon-like gnathopod is included.

KEY WORDS. Isopoda, Asellota, Carpias, Janaira, Echinaster brasiliensis
\end{abstract}

The janirid asellotes are very common isopods found in algal substrata, kelps and corals, mainly in the shallow warm waters of the world oceans. The asellotes of the northern coast of São Paulo State, southeastern Brazil, have been studied since 1977, as reported by MOREIRA \& PIRES (1977) and PIRES (1977a, 1980a, 1981a,b, 1982).

However, the isopod fauna of São Sebastião Channel area still remain poorly known. Only Valvifera (MOREIRA 1973 a,b,c; PIRES 1984) and Sphaeromatidae (PIRES 1980b) were studied, and up to now there is only a brief report about the Asellota (PIRES 1982).

This paper reports the occurrence of three species of janirid living on the dorsal surface of the sea star Echinaster brasiliensis collected in São Sebastião area. One species, Carpias asterophilus, sp.n. is described. The present material was sent to me for study by Dr. S.A. Vanin, Instituto de Biociências, Universidade de São Paulo, to whom I am indebeted.

\section{MATERIAL AND METHODS}

Twelve sea stars were collected by diving in shallow water, from four to six meters depth, in November 1992, at Laje do Moleque, São Sebastião Channel $\left(23^{\circ} 49^{\prime} \mathrm{S}, 45^{\circ} 24^{\prime} \mathrm{W}\right)$. The live material was transported to São Paulo, and kept in the laboratory of the Zoology Department, Instituto de Biociências, Universidade de São Paulo, for observation.

1) Instituto Oceanográfico, Universidade de São Paulo. Caixa Postal 9075, 01065-970 São Paulo. Brasil. 
Each sea star was transferred to a Petri dish with sea water. The presence of isopods was confirmed, and their behavior observed under binocular estereomicroscope. After that, sea water was changed by freshwater in the Petri dishes. Ten minutes later the dead isopods were picked up with a pipette, and placed in vials with $70 \%$ alcohol. Both the sea stars and vials were numbered (1 to 12), and the vials received the same number as the sea star from whom the isopods were obtained.

At the Benthic Ecology Lab, Instituto Oceanográfico da USP, each specimen of Echinaster brasiliensis was measured, from its oral cavity to the distal part of the longest arm. The isopods were identified, sexed and counted. Juveniles of the three species are extremely similar, and as they were collected together their identitication became impossible.

\section{RESULTS}

Observation of the living animals showed homeochromy among the isopods and the sea stars. The three species of isopods shared a similar reddish orange coloration with dark spots. It is well possible they eat the orange mucus secreted by the epidermis of the sea stars. Although food behavior could not be directly observed due the small size of the crustaceans, the examination of mouthpieces and gnathopods showed these pieces involved by the organic material produced by the sea star. But it is not only food that the isopods obtain from that association. When disturbed by tweezers, the asellotes went down the Echinaster body searching for shelter in the ambulacral grooves of the sea star.

The isopods found summed 308 individuals belonging to three species: Janaira gracilis Moreira \& Pires, 1977, Carpias nereus (Pires, 1982) and Carpias asterophilus, sp.n..

The number of individuals and distribution of the asellotes in each sea star is showed in table I.

Juveniles highly dominated in number (about 73\%) followed by females (19\%) and males (8\%). Juveniles could not be identified due their extreme similarity. From the three species, males of Carpias asterophilus were more numerous. The three species were found together in each sea star, and juveniles occurred in 11 out of 12 Echinaster brasiliensis. In the fixed specimens, it was observed a large quantity of whittish soft organic material on dorsal surface of the sea star as well as in the legs and antennae of the isopods.

Carpias asterophilus was previously collected in 1990 at São Sebastião Channel also from the dorsal surface of Echinaster brasiliensis. A number of nine individuals were obtained, a single male and eight females.

The material examined is deposited in Museu de Zoologia, Universidade de São Paulo (MZSP), Museu Nacional do Rio de Janeiro, Universidade Federal do Rio de Janeiro (MNRJ) and Instituto Oceanográfico, Universidade de São Paulo (IOUSP). 
Table I. Distribution of the janirid species in each specimen of Echinaster brasiliensis, numbered 1 to 12 . The measure of $E$. brasiliensis refers to arm length, in milimeters. $(\mathrm{Nr})$ Number of individuals, "Juveniles" are considered individuals of the three species.

\begin{tabular}{|c|c|c|c|c|c|c|c|c|c|}
\hline \multicolumn{2}{|c|}{ E. brasiliensis } & \multicolumn{2}{|c|}{ C. asterophylus } & \multicolumn{2}{|c|}{ C. nereus } & \multicolumn{2}{|c|}{ J. gracilis } & \multirow{2}{*}{$\frac{\text { Juveniles }}{\text { No. }}$} & \multirow[t]{2}{*}{ Total } \\
\hline & Size & Male & Female & Male & Female & Male & Female & & \\
\hline 1 & 46 & 2 & 5 & 2 & 6 & 0 & 0 & 36 & 51 \\
\hline 2 & 47 & 5 & 2 & 0 & 0 & 0 & 0 & 30 & 37 \\
\hline 3 & 38 & 0 & 0 & 0 & 0 & 0 & 2 & 13 & 15 \\
\hline 4 & 39 & 0 & 0 & 0 & 1 & 0 & 0 & 19 & 20 \\
\hline 5 & 34 & 1 & 3 & 4 & 9 & 0 & 0 & 9 & 26 \\
\hline 6 & 46 & 0 & 0 & 0 & 0 & 0 & 5 & 21 & 26 \\
\hline 7 & 31 & 2 & 0 & 0 & 3 & 0 & 10 & 2 & 17 \\
\hline 8 & 36 & 3 & 0 & 0 & 0 & 2 & 4 & 0 & 9 \\
\hline 9 & 46 & 0 & 0 & 0 & 0 & 1 & 5 & 24 & 30 \\
\hline 10 & 58 & 0 & 2 & 0 & 0 & 0 & 0 & 22 & 24 \\
\hline 11 & 39 & 0 & 0 & 0 & 0 & 0 & 0 & 19 & 19 \\
\hline 12 & 41 & 1 & 0 & 2 & 2 & 0 & 0 & 29 & 34 \\
\hline Total & & 14 & 12 & 8 & 21 & 3 & 26 & 224 & 308 \\
\hline
\end{tabular}

\section{Janaira gracilis Moreira \& Pires, 1977}

Janaira gracilis Moreira \& Pires, 1977: 25-31. Figs 1-19: Müller, 1990: 207.

Material examined. Brazıl, São Paulo: São Sebastião Channel (Laje do

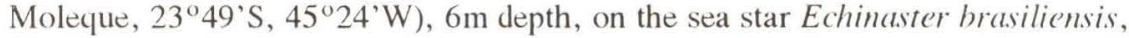
17-XI-1992, three males, 26 females, from 2.0 to $2.2 \mathrm{~mm}$ long, A.C. da Motta \& S.A. Vanin leg. .

Remarks. Janaira gracilis is the most common and abundant isopod found in algal substrata of Ubatuba region, northern littoral of São Paulo State. The species was found in the lower part of midlittoral, infralittoral fringe and shallow sublittoral, living on the holdfasts and leaves of red and brown algae (Galaxaura stupocaulum, Laurencia scopata, Dictyota ciliolata, Dictyopteris delicatula and Sargassum (ymosum) (PIRES 1977b, 1981b). In Echinaster surface, Janaira gracilis was relatively less numerous.

\section{Carpias nereus (Pires, 1982)}

Bagatus nerens Pires, 1982: 254-257. Figs 85-105.

Material examined. Brazil, São Paulo: São Sebastião Channel (Laje do Moleque, 234' S, $\left.45^{\circ} 24^{\prime} \mathrm{W}\right), 4$ to $6 \mathrm{~m}$ depth, on the sea star Echinaster brasiliensis, 17-XI-1992, eight males, 21 females, from 2.4 to $2.6 \mathrm{~mm}$ long, A.C. da Motta \& S.A. Vanin leg. .

Remarks. The species was previously reported from Uhatuba and São Sebastião, northern São Paulo State coast and from Arraial do Cabo, Rio de Janeiro, living in the shallow infralittoral region, among algae (Sargassum, Cheilosporum), mussel beds and under stones (PIRES 1982). The specimens here studied matched with Echinaster brasiliensis the color pattern: reddish orange with dark orange spots. 


\section{Carpias asterophilus, sp.n.}

\section{Figs 1-22}

Holotype male. BRazil, São Paulo: São Sebastião Channel (Laje do Moleque, 4 to $6 \mathrm{~m}$ depth) on the sea star Echinaster brasiliensis, 17-XI-1992, A.C. da Motta \& S.A. Vanin leg., MZSP. Paratypes. 13 male, five female. Seven paratypes MZSP, six paratypes MNRJ, five paratypes IOUSP; 12-XI-1990, one male, eight females, J.M. de Oliveira \& S.A. Vanin leg., IOUSP.

Diagnosis. Male pereopod I propodus surpassing outer distal margin of carpus, ventral margin with two teeth; carpus with two apical teeth, innermost longest triangular, both separated by wide, short, rounded lobe.

Description. Male holotype $2.4 \mathrm{~mm}$ long (Fig. 1). Body nearly three times longer than wide, pereonite VI longest, pereonites II to VI widest, coxal plates visible in dorsally on all pereonites; dark orange in color with brown eyes.

Head about twice wider than long, eyes large, elongate, dorsolateral.

Pereonites I and VII subequal in length and width, slightly narrower than the other pereonites; pereonites II to VI of the same width, pereonites II, III, V of the same length; pereonite VI longest, nearly twice longer than shortest pereonite IV.

Pleon with short embedded pleonite; pleotelson rounded, almost as long as wide, lateral margins bearing minute triangular projection at distal third.

Antenna 1 (Fig. 2). Peduncle of four few setose articles, basal article as long as articles 2 to 4 together; flagellum 7 -articulated, distal 3 articles with single aesthetasc. Antenna 2 (Fig. 3) longer than body; peduncular article 4 about 1.4 times longer than articles 1-3 together, slightly shorter than article 5, squama on distal outer corner of article 2 surpassing article 3; flagellum pluriarticulated.

Mandible (Fig. 4). Palp with article 2 nearly 1.6 times longer than article 1, having two elongate setae latero-distally placed; article 3 as long as first article, outer margin strongly curved inwards, apex truncate with four long setae, inner margin fringed with short setae. Incisor with five teeth, lacinia with four teeth. Setal row with 10 serrate setae. Molar process large, truncate, with some distal setae.

Maxilla 1 (Fig. 5). Outer lobe with six apical serrate spines decreasing in length inwards, lateral margins setose at distal half; inner lohe having several elongate setae apically and sub-apically placed. Maxilla 2 (Fig. 6). Outer lobes 1 and 2 with three and two stout long serratae spines respectively and one smaller serrate spine distally placed; innermost lobe having five apical serrate spines, lateral margin setose.

Maxilliped (Fig. 7). Exopod elongate, almost reaching distal margin of palpal article 2. Articles 4 and 5 of palp almost subequal in length, apex of last article fringed with elongate setae. Inner margin of endite bearing two couplinghooks.

Pereopod I subchelate (Figs 8-9), shorter than body. Basis nearly 1.7 times and merus about 1.4 times longer than ischium, many long setae placed at outer 


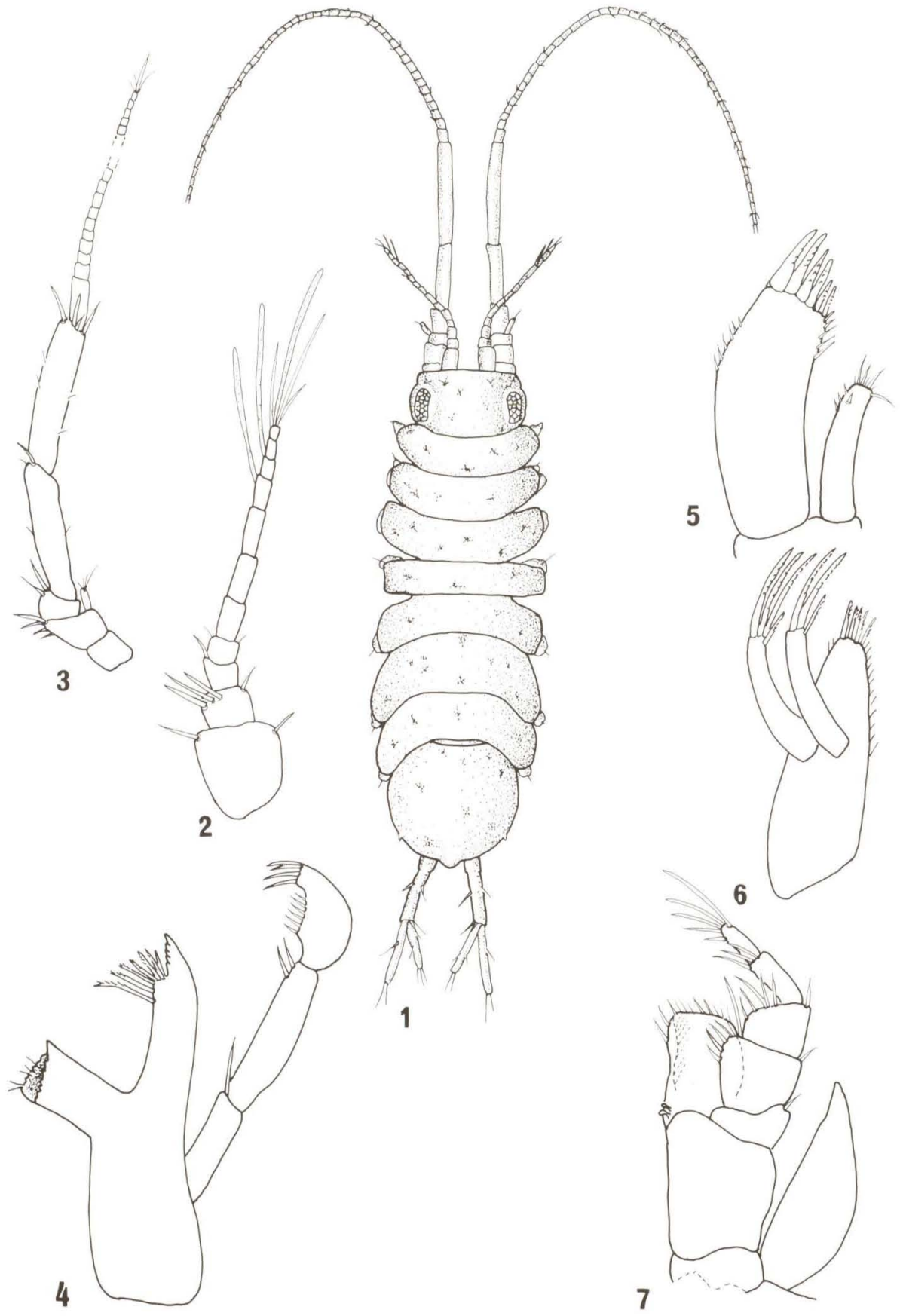

Figs 1-7. Carpias asteriophilus, sp.n.. (1) holotype adult male, $2.4 \mathrm{~mm}$ long; (2-7) paratype adult male, $2.2 \mathrm{~mm}$ long. (1) Body, dorsal; (2) antenna 1, left; (3) antenna 2, left; (4) mandible, left; (5) maxilla 1, left; (6) maxilla 2, left; (7) maxilliped, left. 


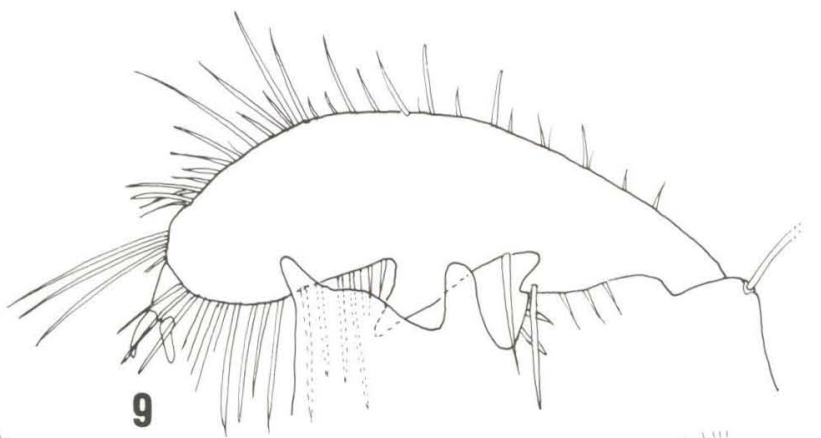

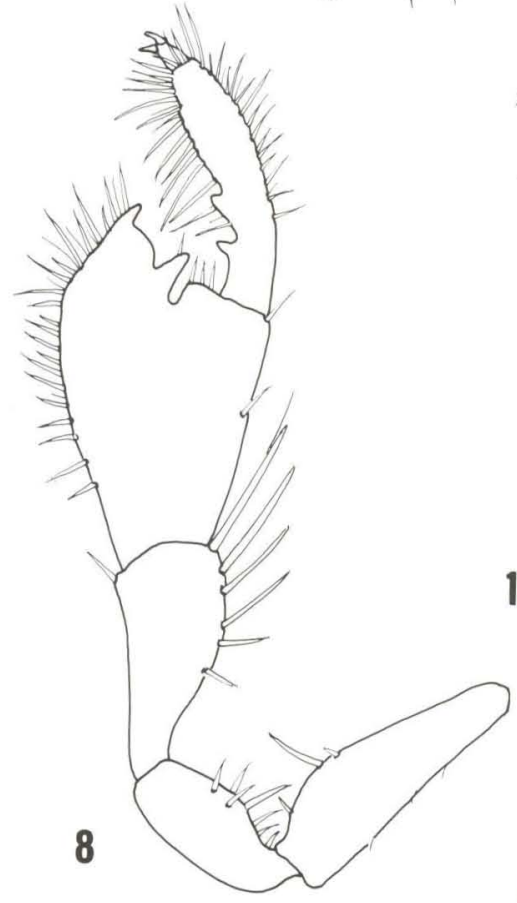

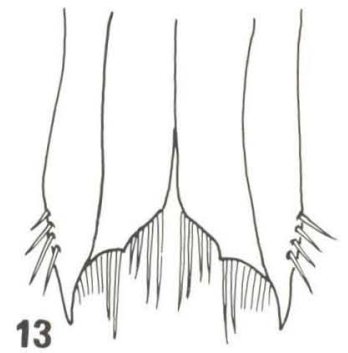

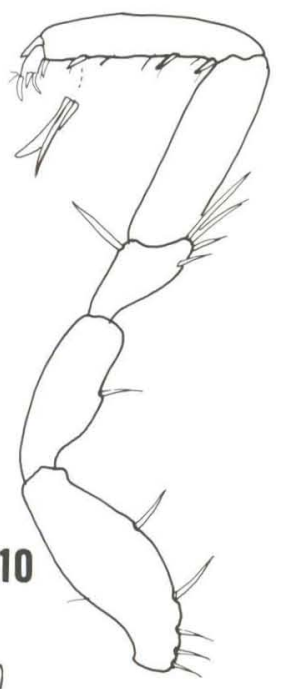

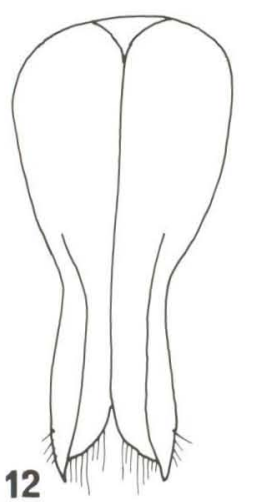

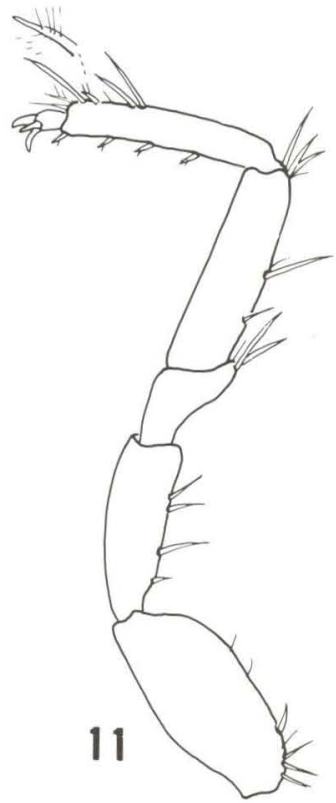

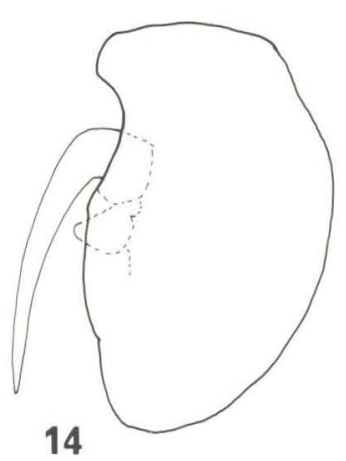

Figs 8-14. Carpias asteriophilus, sp.n., paratype adult male, $2.2 \mathrm{~mm}$ long. (8) Pereopod I, left; (9) pereopod I, distal part; (10) pereopod II, left; (11) pereopod VII, left; (12) pleopod $1 ;$ (13) pleopod 1, distal part; (14) pleopod 2. 
margins of both segments. Carpus slightly longer than propodus, enlarged, spoon-like; outer margin convex at distal quarter, fringed with many setae; upper margin with two teeth, proximal largest, separated by medial short round lobe. Propodus surpassing distal margin of carpus, widest at distal third, ventral margin bearing two proximal teeth, anterior and posterior margins densely setose. Dactylus nearly eight times shorter than propodus, slightly longer than wide, bearing two ungues. Pereopods II to VII similar, ambulatory, dactylus with three ungues (Figs 10-11); peropods VI and VII slightly longer than the others, outer distal margin of propodus with elongate and plumose setae.

Pleopod 1 (Figs 12-13) larger at base, tapering distally up to about $3 / 5$ th, widening slightly towards end; apex obliquely truncate with a small tubercle midway, outer side ending in acute triangular lobe (Fig. 13). Pleopod 2 (Fig. 14) copulatory organ short, almost reaching distal margin of sympod. Pleopod 3 (Fig. 15) exopod slightly longer than endopod, apex bearing one simple setae; endopod fleshy, wrinkled, nearly 3.5 times wider than exopod, distal margin with one inner and two outer subequal, stout, plumose setae. Pleopod 4 (Fig. 16) exopod thin, wide, triangular, slightly surpassing half length of endopod; endopod tleshy, wrinkled, bare, apex rounded. Pleopod 5 (Fig. 17) fleshy, wrinkled, bare, slightly shorter than pleopod 4 , distal margin having small round protuberance.

Uropod (Fig. 18) nearly 1.2 times longer than pleotelson; basis as long as half pleotelson length; exopod about $2 / 3$ rd endopod length, as long as hasis.

Adult ovigerous female, $2.1 \mathrm{~mm}$ long. Females differ from males in having pereopod I ambulatory and pleopod 2 fused in an operculum.

Pereopod I (Fig. 19) similar in outline to the others, differing by being slightly smaller and having dactylus with two ungues. Pereopods II to $\mathrm{V}$ of the same length, shorter than longest pereopods VI and VII, dactylus of three ungues (Fig. 20).

Operculum (Fig. 21) almost 1.4 wider than long, twice larger at middle than in the hase, apex centrally concave fringed with 13 short setae (Fig. 22).

Total length. Adult males 1.9-2.4mm, adult females 1.9-2. $1 \mathrm{~mm}$; juveniles, from manca stage up to $1.7 \mathrm{~mm}$.

Distribution. The species is only known from the type-locality.

Habitat. The species was found on the dorsal surface of Echinaster brasiliensis, from 4 to $6 \mathrm{~m}$ depth.

Etymology. The name is derived from the Greek words asteros (=star) and philos (= friend), and refers to the observed affinity of the species to the sea star Echinaster brasiliensis, used as habitat by Carpias.

Remarks. The males of Carpias asterophilus differ from the other species of the genus by having pereopod I propodus supassing carpus width; by the unique feature of: pereopod I carpal teeth, pleopod 1 apex, setal morphology of the pleopod 3 endopod and shape of the pleopod 4 exopod. Adult females differ slightly from the other species by the degree of apical concavity and setation of operculum. However, these characteristics are difficult to evaluate requiring experience for identification of the species. 


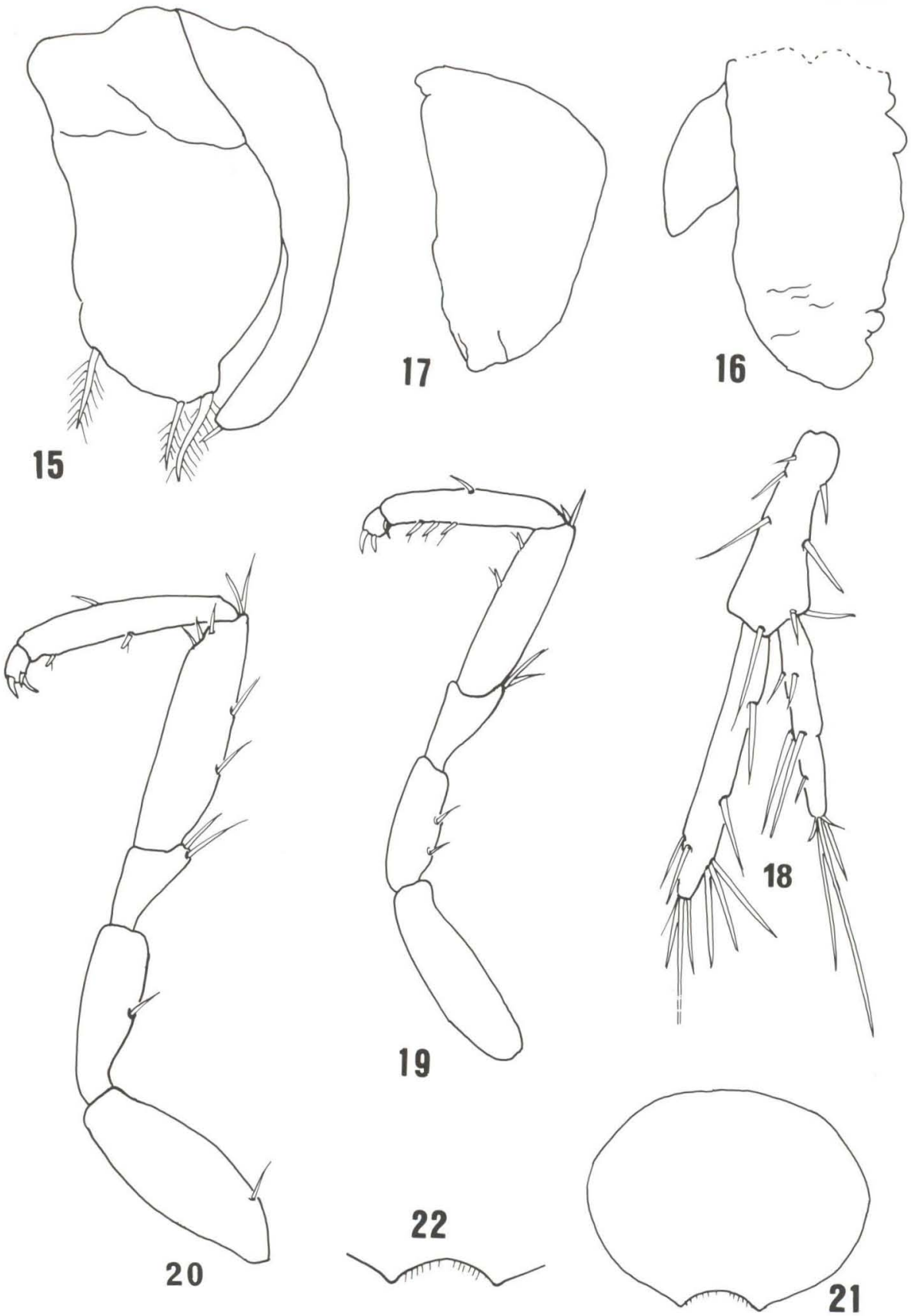

Figs 15-22. Carpias asteriophilus, sp.n.. (15-18) Paratype adult male, 2.2mm long; (19-22) paratype ovigerous female, $2.1 \mathrm{~mm}$ long. (15) Pleopod 3, left; (16) pleopod 4, left; (17) pleopod 5, left; (18) uropod, left; (19) pereopod I, left; (20) pereopod VII, left; (21) operculum; (22) operculum, distal part. 
Discussion. The generic status of Carpias and Bagatus are controverted. The genera were synonymized (MENZIES \& GLYNN 1968; BOWMAN \& MORRIS 1979) or considered valid (PIRES 1980a: MüLLER 1992) many times in the recent years. WILSON \& WÄGELE (1994) presented a systematic review of the Janiridae, retaining the synonymy of Carpias and Bagatus "because the two genera cannot be clearly defined". As stated by WILSON (1994), detailed morphological studies are required on many genera to improve the phylogeny of the Janiridae.

A phylogenetic analysis of the Janiridae was also presented by WILSON (1994), as a first approach for redefining the relationships among the genera. However, even this work did not resolved the definition of Carpias and does not result in a new definition or reclassification of the Janiridae.

Trying to resolve the relationships between Carpias and Bagatus, all the genera with a developed subchela was examined and it was not found any synapomorphy for Bagatus, which remains paraphyletic. So, the best form to avoid confusion is to consider Bagatus and Carpias synonyms. Within the genus thus redefined, a monophyletic group of species characterized by the synapomorphy of carpus of pereopod I in adult males swollen, with a spoon-like concavity ventrally in the upper distal part, postero-distal margin globose directed inward, distal margin oblique, toothed, having outer part higher than inner part is recognized. This group agrees with Carpicas sensu PIRES (1980a, 1981a, 1982). The four species of Carpias with a spoon-like gnathopod in males are keyed below.

\section{Key to the species of Carpias with a spoon-like gnathopod based on adult males}

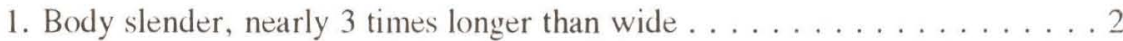

- Body wide, equal or less than 2.6 times longer than wide . . . . . . . . 3

2. Carpus of pereopod I distal margin with three tooth-shaped processes; propodus reaching outer distal corner of carpus, apex bilobed, ventral margin with 1 proximal teeth; pleopod 1 apex bilobed.. . . . . . . . . . . harrictac

- Carpus of pereopod I distal margin with 2 tooth-shaped processes; propodus surpassing outer distal corner of carpus, apex globose, entire, vental margin with two proximal teeth; pleopod 1 apex with single outer lobe . . . . . . .

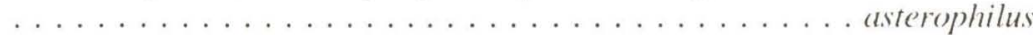

3. Pereopod I basis and merus elongate, subequal in length; distal margin of carpus with four tooth-shaped processes; propodus ventral margin with two processes, unguis minute . . . . . . . . . . . bermudensis

- Pereopod I basis nearly 1.8 times longer than triangular merus; distal margin of carpus with three tooth-shaped processes; propodus ventral margin with single process, unguis well developed . . . . . . . . . . deodatus

\section{REFERENCES}

Bowman, T.E. \& B.F. Morris. 1979. Carpias Richardson 1902, a senior 
synonym of Bagatus Nobili 1906, and the validity of Carpias mimutus (Richardson, 1902) (Isopoda: Asellota: Janiridae). Proc. Biol. Soc. Wash. 92 (3): 650-657.

MENZIES, R.J. \& P. GLYNN. 1968. The common marine isopod Crustacea from Puerto Rico: a handbook for marine biologists. Stud. Fauna Curaçao and other Carib. Isl. 27: 1-133.

MOREIRA P.S. 1973a. Arcturella sawayae, a new species of Isopoda Crustacea from southern Brazil. Bol. Zool. Biol. Mar., N.S. 30: 185-194.

. 1973b. Behavioral aspects of Arcturella sawayae Moreira, 1973 (Crustacea, Isopoda, Valvifera). Bol. Zool. Biol. Mar., N.S. 30: 195-216. 1973c. Food and feeding behavior of Arcturella sawayae Moreira, 1973 (Crustacea, Isopoda, Valvifera). Bol. Zool. Biol. Mar., N.S., (30): 217-232. MoreIRA, P.S. \& A.M.S. PIRES. 1977. Aspects of the breeding biology of Janaira gracilis Moreira \& Pires (Crustacea, Isopoda, Asellota). Bolm Inst. oceanogr., São Paulo, 26: 181-199.

Müller, H-G. 1990. Janiridae from the Caribbean Sea of N-Colombia. Senckenbergiana biol. 70: 203-207.

1992. Janirid from Malasyan coral reefs, with description of two new species of Bagatus Nobili, 1906 and Carpias Richardson, 1902 (Crustacea: Isopoda: Asellota). Mitt. zool. Mus. Berlin 68: 331-43.

PIRES, A.M.S. 1977a. Jamaira gracilis, a new genus and species of janirid isopod from Brazil. Crustaceana 33 (1): 23-32.

1977b. Ciclo evolutivo e flutuação anual da população de Jamaira gracilis (Crustacea, Isopoda, Asellota). Bolm. Inst. oceanogr., São Paulo, 26: 201-217.

- 1980a. Revalidation and redescription of the genus Carpias Richardson, 1902 (Isopoda, Asellota). Crustaceana 39 (1): 95-103.

1980b. New record of Sphaeromatidae (Isopoda) from the Brazilian southern coast: Dynamenella dianae (Menzies, 1962). Crustaceana 39 (2): $133-140$.

1981a. Carpias harrieatae (Isopoda, Asellota), a new species from Florida. Crustaceana 40 (2): 206-212.

1981b. Ecological study on littoral and infralittoral isopods from Ubatuba, Brazil. Bolm Inst. oceanogr., São Paulo, 30: 27-40.

1982. Taxonomic revision of Bagatus (Isopoda, Asellota) with a discussion of ontogenetic polymorphism in males. J. nat. Hist. 16: 227-259. 1984. Taxonomic revision and phylogeny of the genus Erichsonella with a discussion on Ronalea (Isopoda, Valvifera). J. nat. Hist. 18: 665-683.

WiLSON, G.D.F. 1994. A phylogenetic analysis of the isopod family Janiridae (Crustacea). Invert. Taxon. 8: 749-766.

WILSON, G.D.F. \& J.-W. W ÄGELE. 1994. Review of the family Janiridae (Crustacea: Isopoda: Asellota). Invert. Taxon. 8: 683-747. 